\title{
Toxicity of the Agents of Trachoma and Inclusion Conjunctivitis
}

\author{
By JANICE TAVERNE, W. A. BLYTH AND P. REEVE \\ M.R.C. Trachoma Research Unit, Lister Institute of Preventive Medicine, \\ London, S.W. 1
}

(Received 3 June 1964)

SUMMARY

The toxicities of strains of trachoma and inclusion conjunctivitis viruses differing in virulence for the chick embryo were compared at different times during their growth in the chick embryo yolk sac. As measured by the ability to kill mice and to induce skin lesions in guinea-pigs, toxicity increased until the time at which embryos began to die. All strains possessed similar particle:toxin ratios. It is considered unlikely that the differing virulence of the strains depends on differences in the amount of toxin per elementary body.

\section{INTRODUCTION}

Reeve \& Taverne (1963) found that for a given dose some strains of trachoma and inclusion conjunctivitis (TRIC) agents kill chick embryos more quickly than others. One explanation suggested was that elementary bodies of fast-killing strains possess more toxin. To test this we compared the toxicity of three fast-killing and three slow-killing TRIC agents. Since comparisons between strains are not valid unless made when toxin to particle ratios are maximum, measurements were made throughout the growth of each strain in the chick embryo yolk sac. Toxicity was titrated by the ability to kill mice injected intravenously and to form skin lesions in guinea-pigs injected intracutaneously; titres were compared with the total number of elementary bodies present in the suspension.

\section{METHODS}

TRIC agents are named according to the system proposed by Gear, Gordon, Jones \& Bell (1963). Their original names used in this paper are given in brackets. Fast-killing variants are suffixed $f$.

TRIC/China/Peking-2/OT $f$ ('T'ang, Chung, Huang \& Wang, 1957).

TRIC/2/SAU/HAR-2/OT (SA2) (Murray et al. 1960) received from Miss L. Hanna, University of California Medical Center, San Francisco.

The variant SA $2 f$ derives from material received from Dr S. Bell of the School of Public Health, Harvard University.

TRIC/ J J /WAG/MRC-1/OT (G1) (Collier \& Sowa, 1958).

TRIC/ J J /GB/MRC-4/ON (LB4) (Jones, 1961) and the variant LB 4 f.

Virus culture. Strains were grown in yolk sacs of 7 -day chick embryos kept at $35^{\circ}$ and candled daily. 
Diluent. Phosphate buffered saline (Dulbecco \& Vogt, 1952) containing streptomycin sulphate $1000 \mu \mathrm{g} . / \mathrm{ml}$. was used.

Virus suspensions. 10 or $20 \%(\mathrm{w} / \mathrm{v})$ suspensions were made by shaking infected yolk sacs in diluent and then discarding the membranes.

Particle counts were made by the dark field method of Reeve \& Taverne (1962), except that treatment with trypsin was omitted, and suspensions were purified by centrifuging at $8000 \mathrm{~g}$ for $20 \mathrm{~min}$. in $\mathrm{M}-\mathrm{KCl}$.

Mouse test. Two-fold dilutions of virus suspensions were injected in $0.5 \mathrm{ml}$. volumes into the tail veins of T.O. mice weighing 10-15 g. Deaths occurring immediately were regarded as non-specific; those occurring up to $48 \mathrm{hr}$ were used to measure the $50 \%$ lethal dose (mouse LD 50) calculated by the method of Reed \& Muench (1938).

Guinea-pig test. 'Half-log' (1/3·16) dilutions of virus suspensions were made. The backs of adult white guinea-pigs weighing 300-400 g. were depilated and $0 \cdot 2 \mathrm{ml}$. volumes of suspension injected intracutaneously. Virus suspensions induced erythematous indurations that reached maximum intensity at $24 \mathrm{hr}$. With high concentrations, lesions became necrotic.

The diameter of erythema varied directly with dilution of virus suspension. With a given suspension there was little variation between the diameters of lesions induced on the backs of ten guinea-pigs or between lesions induced at different places on the backs of individual animals. The standard error was less than $10 \%$ whether a lesion of 10 or $5 \mathrm{~mm}$. diameter was taken as the end-point. For greater sensitivity the end-point chosen was the reciprocal of the highest dilution giving a lesion with a diameter of at least $5 \mathrm{~mm} .24 \mathrm{hr}$ after injection.

\section{RESULTS}

All strains tested were toxic for mice and induced skin lesions in guinea-pigs. Uninfected yolk sac suspensions never killed mice; they sometimes induced lesions in guinea-pigs but never beyond a dilution of $10^{-1 \cdot 5}$.

Groups of eggs were inoculated with different amounts of virus; each group was sampled daily by harvesting yolk sacs from two to four live embryos, making a suspension, titrating it in mice and guinea-pigs and estimating the total particles present. Virus suspensions induced measurable lesions in guinea-pigs 4-5 days, and killed mice 1-2 days before the first chick embryo deaths occurred. The results of a representative experiment are given in Table 1 . In terms of their effect on mice and guinea-pigs, suspensions contained most toxic material around the mean death time of the group of embryos. Suspensions made from dead embryos induced skin lesions in guinea-pigs but rarely killed mice. A similar pattern was observed for all strains, but the interval between inoculation of embryos and first appearance of toxin, and the time of its maximum titre varied with the strain as well as the dose. For example, when 25 ELD50 of SA2 $f$ were inoculated, the mean death time of the embryos was $\mathbf{7 . 5}$ days and the toxicity for mice was greatest on the seventh day, whereas with 40 ELD50 of LB 4 the mean death time was 10.3 days and toxicity was maximum 10 days after inoculation.

Although toxicity increased during the growth cycle, the ratio of elementary bodies to mouse LD50 showed no consistent pattern of change and for all strains 
Table 1. The toxicity of yolk sacs from live eggs harvested at various times from groups of eggs receiving different doses of agent $L B 4$

\begin{tabular}{|c|c|c|c|c|}
\hline $\begin{array}{l}\log _{10} \\
\text { egg LD50 } \\
\text { inoculated }\end{array}$ & $\begin{array}{l}\text { Mean death } \\
\text { time of } \\
\text { group (days)* }\end{array}$ & $\begin{array}{l}\text { Day sample } \\
\text { taken }\end{array}$ & $\begin{array}{c}\log _{10} \\
\text { mouse LD50 } \\
\text { per yolk sac } \\
\text { sampled }\end{array}$ & $\begin{array}{c}\text { Guinea-pig skin } \\
\text { lesion dose } \dagger \\
\text { per yolk sac } \\
\text { sampled }\end{array}$ \\
\hline $3 \cdot 4$ & $7 \cdot 5$ & $\begin{array}{l}5 \\
6 \\
7 \\
8\end{array}$ & $\begin{array}{l}<1 \\
1 \cdot 3 \\
1 \cdot 4 \\
1 \cdot 1\end{array}$ & $\begin{array}{l}3 \cdot 3 \\
4 \cdot 8 \\
4 \cdot 6 \\
4 \cdot 3\end{array}$ \\
\hline $1 \cdot 6$ & $10 \cdot 3$ & $\begin{array}{r}7 \\
8 \\
9 \\
10 \\
11\end{array}$ & $\begin{array}{l}<1 \\
1.3 \\
1.4 \\
1 \cdot 6 \\
1 \cdot 6\end{array}$ & $\begin{array}{l}3 \cdot 1 \\
3 \cdot 5 \\
5 \cdot 1 \\
6 \cdot 1 \\
4 \cdot 5\end{array}$ \\
\hline $0 \cdot 3$ & $11 \cdot 3$ & $\begin{array}{r}9 \\
10 \\
11 \\
12\end{array}$ & $\begin{array}{l}<1 \\
1.3 \\
1.5 \\
1.7\end{array}$ & $\begin{array}{l}3 \cdot 4 \\
4 \cdot 3 \\
6 \cdot 9 \\
5 \cdot 8\end{array}$ \\
\hline
\end{tabular}

* $\Sigma$ (no. embryos dying $\times$ day after inoculation on which each died)

$$
\text { total no. embryos dying }
$$

$\dagger$ Reciprocal of highest dilution giving a $5 \mathrm{~mm}$. lesion in guinea-pigs injected intracutaneously expressed as $\log _{10}$.
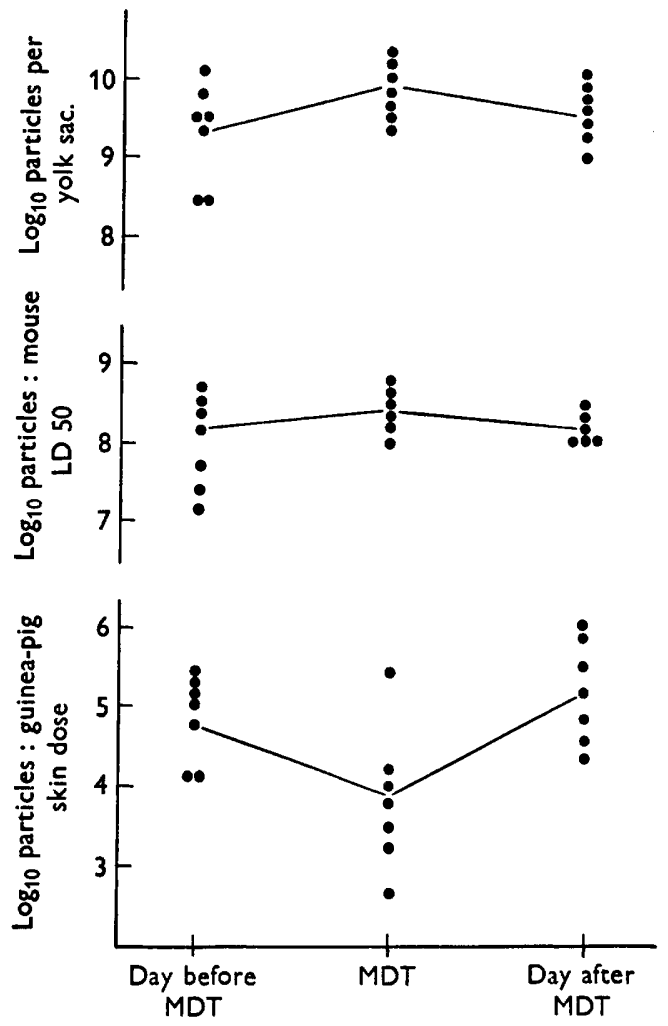

Fig. 1. The total number of particles in a yolk sac and the ratios of total particles: mouse LD 50, and total particles:guinea-pig skin dose around the mean death time (MDT) of groups of infected chick embryos. Six strains were tested, one twice. The lines connect the mean of each group of values. 
Table 2. Toxicity and particle: toxicity ratios of suspensions of TRIC agents that killed mice

\begin{tabular}{|c|c|c|c|c|c|}
\hline Strain & $\begin{array}{c}\text { *Total } \\
\text { particles } \\
\text { per yolk sac }\end{array}$ & $\begin{array}{l}\text { Mouse LD50 } \\
\text { per yolk sac }\end{array}$ & $\begin{array}{l}\text { Guinea-pig† } \\
\text { skin dose } \\
\text { per yolk sac }\end{array}$ & $\begin{array}{l}\text { Particles: } \\
\text { mouse LD50 }\end{array}$ & $\begin{array}{l}\text { Particles: } \\
\text { guinea-pig } \\
\text { skin dose }\end{array}$ \\
\hline LB4 & $\begin{array}{r}8 \cdot 5 \\
8 \cdot 6 \\
8 \cdot 6 \\
8 \cdot 6 \\
8 \cdot 9 \\
9 \cdot 1 \\
9 \cdot 5 \\
9 \cdot 6 \\
9 \cdot 6 \\
9 \cdot 6 \\
10 \cdot 0 \\
10 \cdot 1 \\
10 \cdot 2\end{array}$ & $\begin{array}{l}1 \cdot 3 \\
1 \cdot 0 \\
1 \cdot 0 \\
1 \cdot 1 \\
1 \cdot 0 \\
1 \cdot 1 \\
1 \cdot 3 \\
1 \cdot 3 \\
1 \cdot 4 \\
1 \cdot 6 \\
1 \cdot 5 \\
1 \cdot 4 \\
1 \cdot 6\end{array}$ & $\begin{array}{l}4.3 \\
4 \cdot 8 \\
4.8 \\
4.3 \\
5 \cdot 3 \\
6 \cdot 3 \\
3.5 \\
4.8 \\
6 \cdot 8 \\
6 \cdot 8 \\
4.5 \\
5.0 \\
6 \cdot 0\end{array}$ & $\begin{array}{l}7 \cdot 2 \\
7 \cdot 6 \\
7 \cdot 6 \\
7 \cdot 5 \\
7 \cdot 9 \\
8 \cdot 0 \\
8 \cdot 2 \\
8 \cdot 3 \\
8 \cdot 2 \\
8 \cdot 0 \\
8 \cdot 5 \\
8 \cdot 7 \\
8 \cdot 6\end{array}$ & $\begin{array}{l}4 \cdot 2 \\
3 \cdot 8 \\
3 \cdot 8 \\
4 \cdot 3 \\
3 \cdot 6 \\
2 \cdot 8 \\
6 \cdot 0 \\
4 \cdot 8 \\
2 \cdot 8 \\
2 \cdot 8 \\
5 \cdot 5 \\
5 \cdot 0 \\
4 \cdot 2\end{array}$ \\
\hline SA2 & $\begin{array}{l}9 \cdot 7 \\
9 \cdot 8\end{array}$ & $\begin{array}{l}1 \cdot 3 \\
1 \cdot 6\end{array}$ & $\begin{array}{l}4 \cdot 5 \\
4 \cdot 0\end{array}$ & $\begin{array}{l}7 \cdot 4 \\
8 \cdot 2\end{array}$ & $\begin{array}{l}5 \cdot 2 \\
5 \cdot 8\end{array}$ \\
\hline G1 & $\begin{array}{r}9 \cdot 3 \\
9 \cdot 6 \\
9 \cdot 8 \\
10 \cdot 0 \\
10 \cdot 2\end{array}$ & $\begin{array}{l}1 \cdot 1 \\
1 \cdot 1 \\
1 \cdot 1 \\
1 \cdot 3 \\
1 \cdot 5\end{array}$ & $\begin{array}{l}4 \cdot 8 \\
4 \cdot 3 \\
6 \cdot 3 \\
6 \cdot 8 \\
6 \cdot 8\end{array}$ & $\begin{array}{l}8 \cdot 2 \\
8 \cdot 5 \\
8 \cdot 7 \\
8 \cdot 7 \\
9 \cdot 0\end{array}$ & $\begin{array}{l}4 \cdot 5 \\
5 \cdot 3 \\
3 \cdot 5 \\
3 \cdot 2 \\
3 \cdot 4\end{array}$ \\
\hline LB $4 f$ & $\begin{array}{r}8 \cdot 5 \\
9 \cdot 0 \\
9 \cdot 6 \\
10 \cdot 1\end{array}$ & $\begin{array}{l}1 \cdot 1 \\
0 \cdot 7 \\
1 \cdot 1 \\
1 \cdot 7\end{array}$ & $\begin{array}{l}4 \cdot 1 \\
3 \cdot 8 \\
6 \cdot 3 \\
5 \cdot 6\end{array}$ & $\begin{array}{l}7 \cdot 4 \\
8 \cdot 3 \\
8 \cdot 5 \\
8 \cdot 4\end{array}$ & $\begin{array}{l}4 \cdot 4 \\
5 \cdot 2 \\
3 \cdot 3 \\
4 \cdot 5\end{array}$ \\
\hline SA2 $f$ & $\begin{array}{l}9 \cdot 5 \\
9 \cdot 8 \\
9 \cdot 8\end{array}$ & $\begin{array}{l}1 \cdot 3 \\
1 \cdot 2 \\
1 \cdot 6\end{array}$ & $\begin{array}{l}5 \cdot 5 \\
5 \cdot 0 \\
5 \cdot 5\end{array}$ & $\begin{array}{l}8 \cdot 2 \\
8 \cdot 6 \\
8 \cdot 2\end{array}$ & $\begin{array}{l}4 \cdot 0 \\
4 \cdot 8 \\
4 \cdot 3\end{array}$ \\
\hline T'ang & $\begin{array}{r}9 \cdot 4 \\
10 \cdot 3\end{array}$ & $\begin{array}{l}1.0 \\
1.9\end{array}$ & $\begin{array}{l}4.0 \\
6.5\end{array}$ & $\begin{array}{l}8 \cdot 4 \\
8 \cdot 4\end{array}$ & $\begin{array}{l}5 \cdot 4 \\
3 \cdot 8\end{array}$ \\
\hline
\end{tabular}

remained within the same limits. For example, with LB4, this ratio varied from $1.6 \times 10^{7}$ to $5 \cdot 2 \times 10^{8}$ (Table 2 ) and fell within these limits with all other strains and the fast-killing variants. The amount of virus necessary to induce a skin lesion in a guinea-pig was always much less than that required to kill a mouse; no great differences were observed between strains. However, for every strain tested, fewer particles were needed to produce a lesion at the mean death time of the eggs than on the day before or the day after (Fig. 1).

\section{DISCUSSION}

We tested the toxicity of strains of trachoma and inclusion conjunctivitis isolated in different laboratories, and of fast-killing variant strains. The toxicity of suspensions for mice always reached a maximum at the mean death time of the group of infected eggs, and although this time depended on the strain, no great differences 
were found in the ratio of total particles to mouse LD 50. With frozen pools of several other strains including T'ang, made at a time likely to give maximum toxicity, Reeve (1964) obtained ratios of particles to mouse LD 50 from $2 \cdot 3 \times 10^{7}$ to $4.5 \times 10^{8}$. Thus all strains tested have given similar results. Furthermore, the toxicity : particle ratio of TRIC agents is similar to that of the meningopneumonitis agent, another member of the psittacosis-lymphogranuloma group (Manire \& Smith, 1959).

The results of the guinea-pig skin test also showed no differences between TRIC strains, including the fast-killing variants. Except at the mean death time of the group of infected eggs, an average of $8 \times 10^{4}$ particles of any strain were required to produce a skin lesion $5 \mathrm{~mm}$. in diameter. At the mean death time, however, only $8 \times 10^{3}$ particles were required; a 10 -fold difference seen with every strain and only at this time. The mouse test did not reflect this change. Little is known about the lethal action of these agents in mice, still less about the causes of the skin lesion in guinea-pigs. The guinea-pig test may measure a toxin different from that killing mice. It is also possible that suspensions made at the mean death time of the chick embryos contain products of damaged yolk sac cells that contribute to the skin lesion but do not kill mice under these conditions. Whether or not TRIC strains were fast-killing in eggs, no differences in toxicity were detected in mice or guineapigs. Differences in the amount of toxin per particle cannot therefore explain the strains' differing virulence for chick embryos.

\section{REFERENCES}

Collier, L. H. \& SowA, J. (1958). Isolation of trachoma virus in embryonate eggs. Lancet, i, 993.

Dulbecco, R. \& Vogt, M. (1954). Plaque formation and isolation of pure lines with poliomyelitis virus. J. exp. Med. 99, 2.

Gear, J. H. S., Gordon, F. B., Jones, B. R. \& Bell, S. D. Jr. (1963). Nomenclature of isolates of virus from trachoma and inclusion blennorrhoea. Nature, Lond. 197, 26.

Jones, B. R. (1961). TRIC virus infections in London. Trans. Ophthal. Soc. U.K. 81, 367.

MANIRE, G. P. \& SMITH, K.O. (1959). Quantitative studies on meningopneumonitis virus. J. Bact. 78, 523.

Murray, E. S., Bell, S. D. Jr., Hanna, A. T., Nichols, R. L. \& Snyder, J. C. (1960). Studies on trachoma. 1. Isolation and identification of strains of elementary bodies from Saudi Arabia and Egypt. Amer. J. Trop. Med. Hyg. 9, 116.

REed, L. J. \& MUENCH, H. (1938). A simple method of estimating fifty per cent endpoints. Amer. J. Hyg. 27, 493.

REeve, P. (1964). Trachoma viruses isolated in the United States. VII. Related toxicity of different strains for white mice. Proc. Soc. exp. Biol., N.Y. 116, 373.

ReEve, P. \& Taverne, J. (1962). A simple method for total particle counts of trachoma and inclusion blennorrhoea virus. Nature, Lond. 195, 923.

Reeve, P. \& TAverne, J. (1963). Observations on the growth of trachoma and inclusion blennorrhoea viruses in embryonate eggs. J. Hyg., Camb. 61, 67.

T'ang, F. F., Chang, H. L., Huang, Y. T. \& Wang, K. C. (1957). Studies on the etiology of trachoma with special reference to isolation of the virus in chick embryo. Chin. med.J. 75, 49. 